Evaluasi: Jurnal manajemen Pendidikan Islam

ISSN (P): 2580-3387, ISSN (E): 2615-2886

DOI : http://doi.org/10.32478/evaluasi.v5i2.653

Article Type : Original Research Article

\title{
PENDIDIK DAN UPAYA MANAJEMEN FORMULASI LEMBAGA PENDIDIKAN ISLAM YANG KREATIF MENGHADAPI MASA PANDEMI COVID -19
}

\author{
Siti Makhmudah
}

STAIM Nganjuk, Indonesia

Corresponding author: makhmudahsiti87@gmail.com

Submission Track:

Submisson $\quad: 26-03-2021$

Accept Submission : 24-07-2021

Avaliable Online : :11-09-2021

Copyright @ 2021 Author

This work is licensed under a Creative Commons Attribution-ShareAlike 4.0

\begin{abstract}
$\underline{\text { Abstract }}$
Based on the survey results, several activities are carried out at home, work from home and study from home. Learning from home is called online (learning with online sites). Since the Covid-19 outbreak, the economic aspect, especially in almost all parts of the world, has declined as well as the world of education, including universities and Islamic boarding schools. The design and implementation of distance learning literacy with the topic of Corona Virus 2019 or Covid-19 aims to avoid a pandemic that is currently spreading thoroughly and is very deadly. The existence of this pandemic does not make the world of education lack sense in developing learning in the world of education. Especially for students who until now the learning system is still using via online as an intermediary to connect the delivery of knowledge but also maintain health protocols and minimize obstacles that occur during the online period. The purpose of this research is that it is hoped that the right formulation and in the right form will be found in the form of the impact that occurs on students / students and teachers / Ustadz / Lecturers / Educators during the current Covid19 pandemic. Since the online school system began in March 2020, it has been implemented, and it has happened not only in Indonesia but also throughout the world. The right formulation in this title is based on the formulation and arrangement in the right form in the form of the impact that occurs on students/students and Teachers/Ustadz/Lecturers/Educators during the Covid-
\end{abstract}


19 pandemic. This research uses a formulation case study research method and the research approach uses a qualitative case study method which is used to obtain comprehensive information on the online learning process at the level of students / students who are still active in the world of higher education and Islamic boarding schools. The results of the study show that: First, there are many obstacles faced by students during the online learning process. Second, the educator factor has an important role in the online learning process and many efforts have been made to overcome the obstacles made by educators. And third, knowing the formulation of the right solution for the obstacles that occur during the online learning process during the pandemic. The results of this research are expected to be able to help smooth the online learning process through the right formulation and in the right form in the form of impacts that occurred during the Covid-19 pandemic.

Key words: Lecture Formulation, Creative Lectures, Covid Pandemic -19

\begin{abstract}
Abstrak
Berdasarkan hasil survey menunjukan beberapa kegiatan yang dilakukan di dalam rumah, bekerja dari rumah dan belajar dari rumah. Belajar dari rumah disebut dengan kata daring (belajar dengan situs online). Semenjak adanya Covid-19, aspek ekonomi terutama hampir diseluruh dunia semakin merosot begitu juga dengan dunia pendidikan, termasuk pada Perguruan Tinggi serta Ponpes. Rancangan dan penerapan literasi pembelajaran jarak jarak jauh bertopik Corona Virus 2019 atau Covid-19 bertujuan untuk menghindari pandemi yang saat ini sedang menyebar secara menyeluruh dan sangat mematikan. Dengan adanya pandemi ini tidak membuat dunia pendidikan kekurangan akal dalam menumbuh kembangkan pembelajaran dalam dunia pendidikan. Terutama bagi siswa/peserta didik yang sampai saat ini sistem pembelajarannya masih menggunakan via online sebagai perantara penyambung penyampaian ilmu pengetahuan tetapi juga tetap menjaga protokol kesehatan dan meminimalisir hambatan-hambatan yang terjadi selama masa daring. Tujuan penelitian ini adalah diharapkan nanti ditemukannya formulasi yang tepat dan dalam bentuk yang tepat berupa dampak yang terjadi kepada para siswa/ peserta didik dan Guru/ Ustadz/ Dosen/ Pendidik dalam masa pandemi Covid-19 sekarang ini. Semenjak sistem sekolah daring dimulai bulan maret 2020 diberlakukan, dan terjadi bukan hanya di Indonesia saja tetapi juga di seluruh dunia. Formulasi yang tepat dalam judul ini berpacu pada rumusan dan susunan dalam bentuk yang tepat berupa dampak yang terjadi kepada para siswa/peserta didik dan Guru/Ustadz/Dosen/Pendidik dalam masa pandemi Covid-19. Penelitian ini menggunakan metode penelitian studi kasus formulasi dan pendekatan penelitiannya menggunakan metode studi kasus kualitatif yang digunakan untuk mendapatkan informasi secara menyeluruh terhadap proses belajar online tingkat siswa/peserta didik yang masih aktif dalam dunia pendidikan tingkat Perguruan Tinggi serta Ponpes. Hasil penelitian menunjukkan bahwa: Pertama, banyak sekali kendala yang dihadapi peserta didik selama proses pembelajaran daring. Kedua, faktor pendidik mempunyai peran penting dalam proses pembelajaran daring dan sudah banyak usaha yang
\end{abstract}


dilakukan untuk mengatasi kendala yang dilakukan pendidik. Serta ketiga, mengetahui formulasi solusi yang tepat dari kendala yang terjadi selama proses pembelajaran daring dimasa pandemi. Hasil penelitian ini nanti diharapkan mampu membantu kelancaran proses pembelajaran daring ini melalui formulasi yang tepat dan dalam bentuk yang tepat berupa dampak yang terjadi dalam masa pandemi Covid-19.

Kata Kunci: Formulasi Sekolah Kreatif, Pandemi Covid -19

\section{A. Pendahuluan}

Pada tahun 2020 awal pembukaan tahun, WHO dikejutkan oleh pandemi mematikan yaitu wabah Virus Corona (Covid -19) yang seluruh negara didunia hampir terinfeksi oleh wabah ini. Semenjak januari 2020 WHO telah memutuskan pernyataannya bahwa dunia masuk dalam darurat global terkait dengan virus ini. (Sebayang, 2020). Hal semacam ini merupakan fenomena yang luar biasa yang terjadi pada abad 21 yang menyerang bumi.(Baihaqi, 2017)

Covid -19 adalah virus yang menyerang saluran pernafasan, virus ini hampir sama dengan gejala flu pada umumnya hanya saja virus ini sangat mematikan, bahkan hanya dengan bersentuhan tangan dan bersin didepan muka dengan jarak kurang 1 meter, maka virus akan sangat mudah tertular. Virus ini muncul pertama kali pada bulan Januari 2020 di indonesia dengan terkonfirmasi 3 orang. Lalu semakin lama semakin melebar luas hingga saat ini ada 20.000 orang lebih. (Wahyono et al., 2020)

UNESCO mempunyai data akurat yaitu negara yang menerapkan penutupan sekolah berjumlah 39 negara, dengan jumlah murid 421.388 .462 lebih. Bahkan China memiliki jumlah pelajar yang menjulang paling banyak yaitu berjumlah sekitar 235 juta lebih pelajar baik dasar maupun Perguruan Tinggi serta Ponpes. Sampai 13 Maret berjumlah 61 negara menerapkan pembatasan belajar termasuk Indonesia. Indonesia yang sekarang ini sangat ketat dengan perbatasan dunia pendidikan dan sedang berada pada krisis paling atas.(Baihaqi, 2017)

Munculnya Covid -19 ini memunculkan dunia baru yang dianggap bumerang bagi semua orang, manusia diseluruh dunia dilanda kepanikan dan kekhawatiran dimana-mana. Pemerintah telah memberi himbauan yang efektif dan efisien kepada rakyatnya untuk menjalankan aktifitas di rumah dan dari rumah. Dalam dunia pendidikan hal semacam ini adalah mimpi buruk yang tidak pernah di bayangkan sebelumnya, begitu juga dengan pekerja swasta, buruh, dan pabrik.

Madrasah dan pesantren adalah lembaga pendidikan Islam di Indonesia. Bagian dari pendidikan Islam, khususnya di madrasah dan pesantren dalam periode globalisasi ini, harus dipersiapkan untuk mengakui dan menghadapi perubahan mekanis dari peristiwa dan kemajuan, yang sebagian besar berasal dari negara luar. Madrasah dan persantren harus menyebabkan 
perubahan dan perubahan untuk membuat usia yang kokoh, usia yang memiliki informasi luas dan dapat menciptakan informasi yang bersumber dari Al-Qur'an dan Hadits. Sehingga dapat menjadikan zaman yang tidak hanya berbuah dalam persoalan yang ketat, namun dapat menghadapi kemajuan ilmu pengetahuan dan inovasi di era globalisasi. Alasan makalah ini membahas tentang kesulitan dan pengaturan pelatihan Islam di madrasah dan sekolah Islam live-in dalam periode globalisasi. Hal-hal yang harus dimungkinkan oleh madrasah dan pesantren dalam meningkatkan pengajaran Islam di masa globalisasi adalah membedakan kesulitan yang dihadapi madrasah dan pesantren, dan memahami bagaimana pengaturan pelatihan Islam harus dimungkinkan untuk mencapai tujuan pendidikan yang ideal.(Fatah, 2014)

Pesantren adalah organisasi pendidikan Islam paling mapan yang sebenarnya ada saat ini. Pesantren mulai dikenal setelah masuknya Islam di Indonesia. Pada saat itulah mulai didirikan lembaga-lembaga edukatif untuk kepentingan Islamic Live in School yang mendidik tentang cinta dan informasi keislaman secara luas dan mendalam mulai dari bidang aqidah, fiqh, tasawuf, sehingga menjadi tengah menuju penyebaran dakwah Islam. Madrasah sebagai salah satu yayasan pendidikan Islam meskipun memiliki alasan tertentu, pelatihan yang dilakukan harus diingat sebagai bagian tak terpisahkan dari kerangka sekolah umum. Ini menyiratkan bahwa pelatihan di madrasah harus memiliki opsi untuk menambah tujuan pengajaran umum. Sangat baik dapat dilihat menurut perspektif asosiasi bahwa madrasah adalah perkumpulan yang mengawasi diri sendiri dalam pelayanan agama, sedangkan jika dilihat menurut perspektif kerangka pendidikan umum cenderung dikatakan bahwa madrasah adalah bagian yang sangat diperlukan kerangka pelatihan publik. (Ahmat \& Suharto, 2017)

Di Madrasah dan madrasah all inclusive sebagai lembaga pendidikan islam harus memiliki pilihan untuk membimbing siswanya untuk bekerja di bidang perancangan, masalah keuangan, dan ilmu cermat yang murni dengan tujuan agar bidang tersebut tidak hanya diklaim oleh lulusan non madrasah saja yang tidak benar-benar memiliki pola pikir yang ketat dan kokoh. Menyikapi era globalisasi yang memiliki pergantian peristiwa yang berbeda, madrasah dan pesantren sebagai lembaga pendidikan Islam harus secepat mungkin mewujudkan sesuatu yang telah menjadi tujuannya, khususnya pencapaian kualitas keislaman dalam perkembangan kebudayaan Indonesia. Budaya Indonesia yang normal adalah seseorang yang inovatif dan bermanfaat. Seorang individu yang dapat diandalkan dan saleh sama menguntungkan dengan memiliki pilihan untuk mendominasi inovasi dan informasi. informasi dalam meningkatkan norma kehidupan. Dengan tujuan agar tujuan ajaran Islam tidak hanya sebagai "warisan sosial". Beberapa upaya yang dapat dilakukan untuk mengatasi kesulitan madrasah dan pesantren di era globalisasi adalah sebagai berikut:(Machsun, 2017) 
a. Sebuah. Menciptakan praktik yang tidak tercemar di madrasah dan pesantren sebagai organisasi pendidikan Islam, khususnya dengan menyesuaikan sisi positif sistem pendidikan yang dibiayai negara dengan kerangka pesantren.

b. Terapkan setiap bagian dari program pendidikan agar memiliki pilihan untuk bekerja lebih ideal, lebih spesifik: segmen tujuan, bagian media, segmen materi segmen esensial, dan segmen penilaian.

c. Mengubah keterampilan pendidik yang dapat dibuktikan. Seperti yang diindikasikan oleh Abuddin Nata, seorang pendidik ahli setidaknya memiliki tiga hal, khususnya:

1) Menguasai bidang informasi, ilmu dan kemampuan presentasi kepada mahasiswa.

2) Memiliki kapasitas untuk menyampaikan informasi yang mereka miliki secara efektif dan efektif.

3) Memiliki karakter dan karakter yang hebat memiliki pilihan untuk membimbing siswa untuk melatih informasi yang diperoleh, sehingga instruktur dapat digunakan sebagai contoh yang baik.

d. Tingkatkan papan.

e. Berikan kantor dan kerangka kerja.

Berkaitan dengan era globalisasi, madrasah dan pesantren perlu melakukan hal-hal pendamping untuk menghadapi era globalisasi, khususnya:

Sebuah. Madrasah dan pesantren harus memiliki opsi untuk benarbenar membangun keseriusan sehingga berpindah dari madrasah dan pesantren dapat bersaing dalam kerjasama yang mendunia.

b. Madrasah dan sekolah pengalaman hidup Islam harus memiliki pilihan untuk memiliki beragam bakat mengingat pekerjaan luar biasa membuka pintu di periode globalisasi saat ini.

c. Madrasah dan pesantren harus fokus dan menjaga kepribadiannya dan tidak kehilangan kualitas fundamentalnya.

d. Madrasah dan pesantren harus melakukan asesmen secara terus menerus dan gigih sehingga penegasan kualitas dapat terwakili

kutip dari ungkapan Azyumardi Azra bahwa madrasah adalah publik selain kelas. dari kata santri yang berarti tempat bagi siswa. Santri berasal dari kata Cantrik yang berarti seseorang yang secara konsisten mengikuti instrukturnya. Istilah santri dari bahasa Tamil mengandung arti bahwa santri adalah pendidik Alquran. Sekolah Islam tinggal mungkin adalah yayasan paling mapan dalam pelatihan Islam di Indonesia.(Asror, 2014)

Ada sekolah Islam semua inklusif sejak berlakunya Islam di Indonesia dengan mengikuti kerangka instruksi ketat yang ada dan diciptakan sebelum munculnya Islam. Sebagai sebuah organisasi pendidikan yang telah berdiri cukup lama di Indonesia, sekolah Islam semua inklusif dipandang memiliki andil besar dalam seluruh eksistensi negara Indonesia. Madrasah dan sekolah Islam tinggal adalah yayasan pendidikan Islam di Indonesia. Istilah "madrasah" 
merupakan ungkapan makanan dari awal kata darasa yang mengandung arti belajar.(Fatah, 2014)

Jadi, tempat belajar siswa bisa disebut dengan madrasah. Istilah madrasah tidak hanya diartikan begitu saja karena madrasah juga bisa diartikan sebagai istana, perpustakaan, masjid, rumah dan lain-lain. Demikian juga, sangat tepat dapat dikatakan bahwa seorang ibu adalah madrasah (pertama) yang masih muda bagi anaknya. Diindikasikan oleh Cece Wijaya, kesulitan madrasah dan pesantren dapat dilihat dari penyesuaian di mata publik di bidang keuangan, sosial, sosial, logis dan inovatif yang mempengaruhi kerangka pembelajaran yang dijalankan.

Kesulitannya adalah sebagai berikut:

1. Masalah pemerintahan

Madrasah dan sekolah madrasah harus memiliki pilihan untuk mengatasi kesulitan di bidang ini secara adil, lebih spesifik berpegang pada prinsip-prinsip yang ditetapkan oleh otoritas publik dalam Undang-Undang Sisdiknas, untuk mencapai tujuan yang ideal, khususnya dengan mengambil minat dan menjadi dinamis dalam hasil. pilihan yang diidentifikasi dengan minat instruktif.

\section{Bidang Kebudayaan}

Salah satu cara hidup negara asing yang sangat mempengaruhi gaya hidup bangsa Indonesia adalah kecerobohan atau seks bebas. Ini adalah ujian yang sangat intens bagi madrasah dan pesantren sebagai landasan edukatif Islam untuk melindungi dan menjauhkan usia bangsa dari hal-hal negatif yang dibawa oleh budaya dari luar. Jika ini diizinkan, kualitas sosial negara ini akan lenyap dalam jangka panjang.

\section{Sains dan Teknologi}

Perkembangan banda atau alat musik modern sangat mempengaruhi interaksi instruktif. Barang atau perangkat modern ini bisa menjadi ujian bagi instruktur dalam menciptakan SDM. Karena perangkat tersebut dapat memberikan efek positif dan efek negatif termasuk keberadaan web. Sehingga motivasi dibalik pengajaran saat ini tidak cukup untuk memberikan informasi, kepercayaan diri, kemampuan, namun harus memiliki pilihan untuk membimbing siswa agar menjadi imajinatif, menguntungkan, kreatif, dan bebas karena saat ini penuh dengan persaingan.

\section{Ekonomi}

Ekonomi adalah bagian penting dari keberadaan suatu negara yang dapat menyebabkan kekurangan, kesana kemari, dan kecepatan lesu kemajuan kerangka pelatihan di suatu negara. Sehingga peran perekonomian di suatu negara sangat berdampak pada perbaikan organisasi-organisasi keislaman.

5. Bidang Sistem Nilai

Kerangka nilai adalah dasar pemikiran dari standar yang digunakan oleh masyarakat sebagai makhluk individu dan makhluk sosial, baik dari prinsip konvensional maupun pedoman ketat yang selama ini ada di arena publik. 
Lebih lanjut, kerangka nilai dapat dimanfaatkan sebagai aksentuasi pada tingkah laku manusia yang dapat mengatur, mengarahkan dan mengendalikan perbaikan masyarakat.

Kata globalisasi berasal dari kata "globe" yang artinya bumi, yang pada dasarnya dapat berarti interaksi yang menjadikan satu dunia atau satu bumi.9 Globalisasi secara total dicirikan oleh para peneliti dunia, misalnya penilaian Baylis dan Smith yang mencirikan globalisasi sebagai sebuah siklus berkembang. hubungan antara area lokal dan peristiwa yang terjadi di tempat tertentu akan mulai mempengaruhi masyarakat dalam jangka panjang. Menurut Anthony Gidden, globalisasi adalah siklus sosial yang digambarkan dengan berkembangnya hubungan sosial yang telah mengglobal. Hal ini mengimplikasikan bahwa individu yang hidup di satu wilayah akan berdampak pada keberadaan individu di tempat yang berbeda, dan sebaliknya.(Nurul Yaqin, 2017)

Globalisasi dapat digambarkan dengan beberapa hal, khususnya: 1) Globalisasi secara tegas diidentikkan dengan perkembangan mekanis dan headway, hanya sebagai jalur perkembangan data untuk berbicara dengan negara-negara luar. 2) Globalisasi tidak dapat dipisahkan dari pengumpulan modal, semakin penting perkembangan usaha, semakin tinggi akun dan pertukaran di seluruh dunia. 3) Globalisasi identik dengan perkembangan individu, nilai dan pemikiran lintas bangsa, seperti halnya perdagangan sosial. 4) Globalisasi digambarkan dengan semakin meluasnya tingkat hubungan dan keterkaitan antar jaringan.(Baihaqi, 2017)

Langkah-langkah yang dilakukan dan diupayakan pemerintah untuk menyeselesaikan kasus ini salah satunya yaitu dengan menerapkan gerakan Social Distanting. Konsep ini menjelaskan bahwa seseorang harus menjaga jarak dengan orang lain miniman 2 meter, menghindari pertemuan rama-ramai dan tidak melakukan sentuhan atau kontak dengan orang lain secara langsung, semua usaha ini dilakukan untuk mengurangi bahkan memutus rantai penyebaran Covid -19. ${ }^{1}$

Pendidik dalam latihan / partisipasi pembelajaran jarak dekat dan pribadi merupakan prasyarat mutlak yang tidak dapat diabaikan, karena instruktur merupakan segmen penting dalam latihan pembelajaran. Instruktur memiliki banyak pekerjaan secara dekat dan pribadi, termasuk sebagai pendidik informatif harus berusaha menjelaskan materi / pesan pembelajaran dengan jelas dan mudah dipahami oleh siswa. Namun demikian, dengan kondisi saat ini selama wabah Corona yang sejalan dengan visi dan misi menuju modern insurgency 4.0, para instruktur dipercaya akan secara konsisten meningkatkan diri dalam pembelajaran internet dengan menggunakan pergantian peristiwa yang inovatif.(Diplan, 2019) 
Tugas pendidik menyinggung tentang visi bangsa Indonesia tentang visi kemajuan mekanik hingga mencapai puncak gemilangnya di tahun 2045. Salah satu syarat yang hingga saat ini sedang diteliti adalah Indonesia sedang menghadapi ujian lain, khususnya modern kesal 4.0. Gejolak mekanis 4.0 merupakan perubahan dahsyat yang memanfaatkan Sistem Fisik Cyber, perpaduan antara ruang-ruang maju, fisik, dan organik sebagai alasan perubahan.(Wahyono et al., 2020) Modern marah 4.0, di mana 75\% pekerjaan meliputi kemampuan sains, inovasi, desain dan matematika, web of things, dan pembelajaran yang tahan lama.

Tentunya ini adalah ujian bagi para instruktur untuk meningkatkan SDM di Indonesia dengan cara-cara baru yang tetap waspada akan berbagai peristiwa namun di sisi lain bertenaga sehingga dapat membantu Indonesia melalui pemberontakan modern 4.0 dan pengakuan visi Indonesia yang cemerlang tahun 2045.(LUBIS, 2020) Untuk menghadapi masa kerusuhan mekanis 4.0, Indonesia perlu meningkatkan sifat kemampuan aset manusia dengan inovasi komputerisasi (Parray, ILO, 2017). Pengakuan ini dilakukan sebagai pembelajaran berbasis web. Hampir semua orang dapat memanfaatkan web. Namun hingga saat ini web belum berhasil dimanfaatkan dan menguntungkan (Nugraha, A.S, Laksono, B, Anarsih, R dan Suswandari, 2019). Oleh karena itu, pengajaran di Indonesia dan pemanfaatan inovasi web timpang. Jadi SDM kita masih belum layak bersaing di era modern 4.0.

Oleh karena itu, pelatihan diterima untuk dapat merencanakan SDM melalui Station Rotation Blended Learning. Station Rotation Blended Learning adalah teknik pembelajaran yang dapat sampai di semua wilayah di Indonesia yang mudah beradaptasi, inventif, dan imajinatif dengan bergantung pada web sehingga dapat bersaing di era transformasi modern 4.0 dan tetap sadar akan kemajuan inovasi dunia dengan tetap mempertahankan sekolah karakter. Pembelajaran campuran sendiri merupakan siklus pembelajaran yang menggabungkan strategi pembelajaran adat (eye to eye) dan internet.(Ningtias, 2018)

Mixed Station Rotation diperlukan untuk memberi energi pada siswa / siswa dalam pembelajaran. Hal ini diidentikkan dengan inspirasi belajar siswa. Sesekali belajar dipandang melelahkan di web sebagai tugas dan tugas sebagaimana sebelumnya. Dengan tujuan agar Blended Station Rotation dapat menjadi perincian lain dalam pembelajaran internet karena dapat mendorong siswa untuk mencari tahu bagaimana mendapatkan inspirasi dalam interaksi pembelajaran dan tugas-tugas online / online. Tiga hal penting yang menguraikan keadaan yang harus segera diperhatikan, di Indonesia, juga oleh seluruh penduduk dunia sehubungan dengan keterpaduan pengajaran, baik selama maupun setelah pandemi. Memang, kami dihadapkan pada masalah yang intens sehubungan dengan "bagaimana latihan instruktif dapat berjalan bahkan dalam keadaan pandemi?" 
Pada setiap tingkat tindakan instruktif, dari taman kanak-kanak hingga yayasan tersier, mereka merasakan sesuatu yang sangat mirip, khususnya ketidakmampuan. Penulis esai ini juga menangkap komposisi Mas Muhammad lqbal, seorang penulis di KTB 7.15 yang mengeluh tentang kondisi pembelajaran berbasis web dan harapan untuk dapat menyesuaikan di kemudian hari. Periode pandemi ini merupakan kekuatan yang signifikan dalam bidang pendidikan. Ini adalah detik penting yang mencerminkan bahwa kita tidak siap menghadapi masa interupsi, khususnya di bidang persekolahan. Mulai dari otoritas publik, pendidik, pelajar hingga wali. Dalam tulisan ini penulis mencoba menginvestigasi ketegangan yang dikomunikasikan oleh teman-teman pada artikel yang lalu (pada KTB 7.15 Selasa-7/7/2020-kemarin) melalui suatu pemikiran yang penulis rasakan, tidak konklusif bagaimanapun juga dapat terus berlanjut. menciptakan, sehubungan dengan reaksi alam semesta sekolah terhadap keajaiban. gangguan di tengah pandemi ini. Gangguan harus dihadapi, bukan dihindari.

Secara luas, pemahaman tentang gangguan yang diketahuinya itu ditarik dari Prof. Rhenald Kasali dalam bukunya yang berjudul Disrupsi yang menyatakan bahwa interupsi adalah sebuah kemajuan. Kemajuan yang akan menggantikan seluruh kerangka lama baru-baru ini. la juga mengatakan bahwa interupsi (pembangunan) merupakan bahaya bagi Petahana (pemegang kekuasaan atau norma). Penghuni sehubungan dengan makalah ini memiliki makna yang luas. Mulai dari kewenangan masyarakat sebagai pemegang kekuatan utama yang berkewajiban untuk memberikan seluruh kerangka pembelajaran, pengajar dan siswa sebagai mata pelajaran dalam mendidik dan mempelajari latihan, hingga wali sebagai mata pelajaran yang sangat diperlukan yang membina dan menyaring jalannya latihan senam tersebut. Apa yang terlihat sekarang adalah penghalang Incumbents untuk kerangka berpikir di web memiliki banyak kelemahan. Apa ini salah? Tentu saja tidak. Mengingat bahwa kita berada dalam fase awal dari periode gangguan pengajaran yang dipicu oleh keadaan pandemi ini.

Kami sebenarnya membutuhkan lebih banyak variasi dan kemajuan untuk mengelolanya. Tidak sedikitpun, menuduh kondisi tersebut dan raguragu untuk berbuat lebih banyak untuk mengalahkannya. Hal inilah yang perlu ditonjolkan oleh sang pencipta, bahwa dalam menghadapi pandemi, kita harus berani berperang. Tidak dalam hal apa pun, menjauhi dan memaafkan penjelasan di balik kebingungan dan saling berhadapan lebih memungkinkan.

Mundur dari pertimbangan Rhenald Kasali, seharusnya ada lebih banyak upaya dalam menghadapi periode interupsi ini; pedoman bermasalah, budaya diruptif, sikap menyusahkan dan iklan yang merepotkan diperlukan. Kelima fokus ini adalah jalan menuju administrasi baru dari sebuah perkembangan di ranah pelatihan yang sekaligus menghancurkan sekaligus imajinatif. 
Korespondensi akses sangat penting Mengingat informasi yang disebarkan Kominfo pada April tahun lalu, ada 24.000 kota di seluruh Indonesia yang belum memiliki akses web. Pencipta merasa bahwa melalui distribusi ini kita dapat melihat peningkatan yang timpang dari fondasi jaringan komunikasi siaran, khususnya web di berbagai wilayah. Pencipta menyadari bahwa ada variabel berbeda di baliknya. Meskipun demikian, seperti yang telah dijelaskan oleh pencipta sebelumnya, kita harus berjuang menghadapi periode ini. Jadi peningkatan kecepatan peningkatan pondasi web menjadi alasan untuk masuk setara dengan pembelajaran berbasis web.

Kami masih berbicara pada tahap keterbukaan, tidak membahas aksesibilitas perangkat keras, tenaga kerja berbakat, dan biaya yang diperlukan. Juga, mirip dengan itu atau tidak yang harus dikatakan oleh penulis esai, kita masih merayap bahkan dengan kenyataan ini.

Dengan tegas penulis sependapat ketika Mas Iqbal dalam karyanya mengatakan, “... .. Merupakan hal mendasar bagi otoritas publik untuk menilai pembelajaran jarak jauh cukup lama. Dengan penilaian tersebut, diyakini akan ada perubahan dalam detailing pelatihan dan pelatihan. Apalagi badan publik akan lebih fokus pada status kantor inovasi data untuk membantu penyuluhan di daerahnya. Sehingga persekolahan bisa dirasakan oleh seluruh masyarakat Indonesia."

Hak istimewa atas pengajaran telah diatur dalam Pasal 31 UUD 1945 yang juga mengandung arti bahwa negara wajib untuk memenuhi itu. Kondisi saat ini dapat dimanfaatkan sebagai batu penjelajah untuk melahirkan kerangka kerja pengajaran lain yang dapat menghadapi masa gangguan seperti mendarah daging dalam kualitas manusia dalam pelaksanaannya. Kemungkinan strategi pembelajaran model lintas ras yang diteliti oleh Menteri Pendidikan dan Kebudayaan Nadiem Makarim yang bekerja sama di web dan pembelajaran vis-à-vis, menurut penulis, merupakan rencana yang menarik untuk dibuat, sambil meningkatkan ketersediaan, memperkuat SDM, dan fokus pada dan jatah pengeluaran yang layak. Salah satu gambaran dari pemikiran yang dapat diciptakan adalah pengembangan panggung untuk sekolah atau perguruan tinggi yang digabungkan dengan setiap kantor kebutuhan mahasiswa / undergrad. Katakanlah dalam aplikasi kita bisa mendapatkan materi, sambil memeriksa kekurangan sial, menghubungi instruktur / pembicara, mendapatkan buku di web, hingga data instruktif penting lainnya. Sebuah pemikiran yang mahal namun tidak layak karena semua penjuru dunia juga merasakan hal yang sama saat ini.

Pencipta merasa terserah pada kemauan politik negara (pemimpin dan penguasa) tentang bagaimana mengelola periode gangguan dalam pengajaran ini, judul mana yang ingin Anda ambil? Semua yang dikatakan pencipta tidak ada gunanya jika negara memiliki kemauan politik yang dapat diabaikan dan lesu untuk berubah. Terlepas dari apakah itu item yang sah, item strategi, dan persyaratan. Akankah kita terus berlari di tempat dengan penalaran biasa, atau 
akankah kita lebih suka terburu-buru mencari setelah periode interupsi yang secara bertahap dihapus? Pembelajaran berbasis web adalah ilustrasi dari ujian asli, jadi seperti yang saya pikirkan, berhentilah mengomel tentang kondisi saat ini. Pada titik itu, pusatkan kerja sama untuk melacak titik kumpul sekolah yang ideal di kemudian hari.

\section{B. Metode Penelitian}

Penelitian ini menggunakan metode studi kasus formulasi dan pendekatan penelitiannya menggunakan metode studi kasus kualitatif yang digunakan untuk mendapatkan informasi terhadap proses belajar online tingkat siswa/peserta didik yang masih aktif dalam dunia Perguruan Tinggi serta Ponpes.

Kondisi pandemi Covid -19 telah menjadikan aktivitas belajar mulai RA. SD, SMP, SMA bahkan sampai Perguruan Tinggi dilakukan sistem belajar dirumah dengan metode belajar jarak jauh (online) disebut dengan daring (Schoolar. Google.Com) Salah satunya yang akan kita bahas adalah pembelajaran online yang dilakukan oleh siswa/peserta didik era 2020. Pasalya banyak kegiatan yang dilakukan secara online termasuk pelunasan belajar setiap mata sekolah yang ada didalam setiap Perguruan tinggi. Hal ini menuntut para Guru/Ustadz/Dosen/Pendidik dan siswa/peserta didik untuk berlomba-lomba menemukan situs pembelajaran yang efektif digunakan yang bisa terbilang lengkap.(Salim, 2019)

Salah satunya pada sekolah / madrasah/ dan perguruan tinggi yang mengadakan sekolah daring sejak bulan maret 2020. Awalnya semua siswa/peserta didik sangat senang dan gembira karena mereka menganggap sekolah daring itu sama halnya dengan liburan walaupun dirumah saja. Akan tetapi sudah setengah jalan barulah mereka mengalami kejenuhan dan merasa tugas tumpukan menjadi tumpukan gunung.

Pelaksanaan sekolah daring tidak bisa dianggap remeh dan enteng, apalagi disepelekan, karena itulah penelitian ini diadakan. Bagian yang paling kritis dari penelitian kualitatif adalah interpretasi data dan analisis, pedoman ini sering digunakanuntuk analisis kejadian dan pendataan. (Creswell, 2009). Didalam buku Alhojailan mengatakan "semua kemungkinan interpretasi adalah mungkin". (Alhojailan, 2012).

\section{Pembahasan}

Daklam pembahasan kali ini akan banyak mengangkut tentang dampak yang dirasakan siswa/peserta didik, Guru/Ustadz/Dosen/Pendidik dan kendaya dan upaya dalam melaksanakan sekolah daring yang beralasankan karena covid-19 ini.

1. Dampak terhadap Siswa/peserta didik

Dampak yang dirasakan para siswa/peserta didik pada proses sekolah di rumah saja adalah mereka merasa belajar jarak jauh tanpa 
sarana dan prasarana memadai di rumah sangatlah sulit. Fasilitas yangdimaksudkan adalah perpustaan sebagai bahan untuk mencari referensi, walaupun masih ada jurnal dan e-book, akan tetapi buku manual adalah yang terbaik bagi siswa/peserta didik. Karena buku sangat penting untuk kelancaran proses pembuatan makalah, tugas dan yang lainya. Dampak selanjutnya yaitu siswa/peserta didik belum pernah melakukan aktifitas semacam ini, yaitu belajar dirumah dengan daring.

Dampak selanjutnya yaitu siswa/peserta didik kesulitan melakukan praktik-praktik sesuai jurusan yang mereka ampu, misal pada jurusan PAUD/PGRA di perguruan tinggi Nganjuk tempat peneliti mengajar akan lebih sering melakukan tepuk, nyanyian, mengembangkan aspek dengan stimulus, membuat mainan, prakti bermain yang efektif dalam kelas. Semua yang seharusnya dituangkan dalam dunia pendidikan suatu saat nanti menjadi terhambat karena adanya covid-19. Tanpa disadari bahwa waktu untuk beradaptasi yang mereka lakukan dan mereka menghadapi perubahan baru yang secara tidak langsung akan mempengaruhi daya serap belajar mereka.

Dengan keadaan seperti ini maka dunia pendidikan diliburkan terlalu lama, keadaan ini membuat banyak siswa/peserta didik menjadi jenuh dan sulit untuk merefress otak. Adanya wabah Covid-19 memaksa para siswa/peserta didik harus mensetujui prosedur belajar dirumah. Agar bisa menggunakan teknologi moderen dalam pembelajaran untuk meningkatkan kualitas siswa/peserta didik, maka perlu adanay layihan kepada teknolgi seain WA saja.

2. Dampak Bagi Guru/Ustadz/Guru/Ustadz/Dosen/Pendidik

Covid -19 tidak hanya menyerang banyak siswa dan siswa/peserta didik, akan tetapi juga guru serta Guru/Ustadz/Guru/Ustadz/Dosen/Pendidik. Kendala yang dialami para Guru/Ustadz/Dosen/Pendidik adalah sulitnya menerjemahkan dan menjelaskan teori-teori yang seharusnya mampu untuk dipraktikkan oleh siswa/peserta didiknya. Adanya Covid-19 yang mewabah ini memaksa para Guru/Ustadz/Dosen/Pendidik untuk menggunakan teknologi baru dan canggih, mau tidak mau harus belajar dan siap memantau proses Perguruan Tinggi serta Ponpes melalui jarak jauh dengan menggunakan teknologi dengan di rumah saja.

Banyak Guru/Ustadz/Dosen/Pendidik juga mengeluhkan jika ketidak nyamanan mereka terjadi saat mereka mulai mengkhawatirkan perkembangan yang seharusanya terjadi kepada siswa/peserta didiknya menjadi terhambat menurut mereka. Pasalnya para Guru/Ustadz/Dosen/Pendidik sulit menjelaskan rumusan kinerja tugasnya jika tdak bertatap muka langsusng, dan itu membuat kali pertamanya pengalaman sekolah daring. 
3. Kendala dan Upaya terhadap siswa/peserta didik dan Guru/Ustadz/Guru/Ustadz/Dosen/Pendidik

Pada siswa/peserta didik Lembaga Pendidikan Di Nganjuk, ada beberapa faktor yang terjadi pada program pembelajaran daring ini, faktor ini adalah salah satu kendala dalam sekolah daring, diambil dari sisi keadaan siswa/peserta didik itu sendiri. Mari kita bahas.

a. Kualitas dan kapasitas HP

Melakukan sekolah daring tentunya harus mempunyai HP android sebagai perantara hubungan pembelajaran, sebagai alat komunikasi, sebagai penyalur tugas dan file-filenya. Akan tetapi yang akan kita bahas kali ini adalah kapasitas HP yang kurang memadahi. Misal: MR.X (anggap saja nama siswa/peserta didik) mengungkapkan bahwa HP miliknya akan mati sendiri jika pesan yang masuk terlalu banyak, akan mati saat melakukan pengunduhan file, akan mati jika untuk membuka file. Itu masih di anggap sedikit dari gangguan HP milik MR.X, karena tidak semua HP siswa/peserta didik memiliki kecanggihan dan kecepatan yang sama. Oleh karena itu kendala ini menyebabkan kurang maksimal untuk melakukan pembelajaran daring. Tidak hanya MR.X, tp juga MR.Z, MR.Y dan masih banyak lagi.

Cara untuk menanggulangi kendala ini tentunya dirundingkan antara MR.X, teman atau siswa/peserta didik lain dan Guru/Ustadz/Dosen/Pendidik setiap matkul. Dan justru menghasilkan suatu gagasan yang murni muncul dari MR.X sendiri, yaitu: MR.X akan mencarger HP sampai penuh dan memindahkan semua file kedalam flashdisk, melalui laptop temannya, dan melakukan pembelajaran on line melalui aplikasi WA seperti biasa meski tidak terlalu lancar. Apabila masih mengalami kemacetan HP maka MR.X akan berbicara dengan Guru/Ustadz/Dosen/Pendidik dan teman-temannya dengan meminta maaf karena memang kendala ini tidak dibuat-buat dan murni adanya. Dengan adanya kemakluman dari teman-teman dan Guru/Ustadz/Dosen/Pendidik saling mengerti, maka MR.X akan lebih giat lagi belajar dengan sendirinya melalui file yang telah dikirimkan pemateri.

b. Susah Signyal dan lokasi

Kendala yang dialami siswa/peserta didik yang ke-dua adalah signyal yang sulit dijangkau karena keberadaan lokasi atau tempat tinggal siswa/peserta didik yang dibilang pelosok atau terpencil. Maka sering sekali terjadi troble dalam berjalannya sinyal. Dengan kendala ini maka akan sulit untuk membuat belajar daring menjadi nyaman dan tenang. Kita sebagai siswa/peserta didikpun juga tidak bisa berbuat apa-apa karena memang tidak bisa membuat signyal.

Cara untuk mengatasi kendala susah signyal yaitu dengan cara MR.Y (sebut saja nama sebagai contoh) pergi ke sebuah lokasi yang 
menurutnya bisa membuat signyalnya mudah di jangkau. Entah di hutan atau alas di pinggir jalan raya atau dimanapun. Siswa/peserta didik yang lain yang mengetahui kenaasan yang terjadi pada MR.Y sangatlah merasa prihatin dan terus memberi semangat.

c. Siswa/peserta didik berkeluarga

Tidak semua anak SMA yang telah lulus langsung melanjutkan ke jenjang Perguruan Tinggi serta Ponpes. Ada beberapa sebagian yang masih sibuk dengan kesibukannya sampai akhirnya memutuskan untuk sekolah meski sudah berkeluarga karena memang usia sudah sudah masuk dalam usia menikah, misal menikah pada usia 22 tahun dan sekolah pada saat itu juga karena memang keadaan yang mengharuskan sekolah, karena sudah mengajar misalnya dan harus mempunyai gelar S1.

Terkait dengan sekolah daring ini adalah salah satu yang dianggap kendala rumah tangga, jangankan sekolah daring, sekolah aktif saja sudah sangat meribetkan jika tidak bisa memberi pengertian pada keluarga dan membagi waktu yang baik. Jika sudah berkeluarga maka akan dibertanggung jawabkan oleh suami. Maka pembelajaran daring akan membuat waktu yang sedikit tersita untuk melakukan aktifitas belajar daring.

Meskipun itu semua bisa dibilang bukan alasan yang baik dan masuk akal, tetapi memang itu semua dianggap kendala. Upaya untuk mengendalikan keadaan semacam itu adalah, siswa/peserta didik yang sudah berkeluarga harus pandai memberi pengertian dengan bahasa dan pemahaman yang baik dan mampu mengatur waktu seadil mungkin. Bisa dibilang keputusan itu adalah tugas pribadi dari siswa/peserta didik demi kebaikan.

d. Ekonomi

Dimana-mana ekonomi masih menjadi kendala yang selalu hadir dalam setiap kasus apapun, termasuk dalam pengembangan sekolah daring ini. Karena kegiatan apapun yang muncul dari on line selalu membutuhkan pulsa data atau sering disebut paketan, dan itupun terbilang tidak murah menurut ekonomi kelas standart bahkan bawah. Apalagi matkul tidak hanya ada satu dua saja dan daringpun dilakukan satu minggu empat hari, mulai dari jam 13.0017.00 WIB

Upaya sementara untuk menanggulangi hal semacam ekonomi ini adalah dengan cara memakai wifi di warung atau di tempat yang memang menyediakan wifi. Karena wifi hanya mengahabiskan uang senilai Rp 3000.00 dan terbilang hemat. 
Ekonomi juga menjadi pemicu terhambatnya UAS dan UTS bagi siswa/peserta didik, karena pembayaran pada Perguruan Tinggi serta Ponpes menjadi terhambat dan menjadikan siswa/peserta didik tidak bisa mendapatkan nomer ujian sehingga sulit untuk mengikuti UAS atau UTS. Banyak siswa/peserta didik yang berharap penuh kepada dewan lembaga Perguruan Tinggi serta Ponpes agar memberi sedikit keringanan dan tenggang waktu secukupnya.

e. Banyak Tugas bersifat tanggung jawab

Sebagian besar siswa/peserta didikLembaga pendidikan di Nganjuksudah banyak yang menjadi guru meski belum menyandang gelar Sarjana. Oleh karena itu banyak juga kewajiban yang harus dikerjakan yang berhubungan dengan lembaga. Misal salah satunya di lembaga RA, guru RA harus mengerjakan BOP, Emis, Simpatika, Pemberkasan, Rakara dan laporan kinerja guru selama daringnya murid-murid setiap minggu dan masih banyak lagi catatan manual. Tugas-tugas tersebut bersifat on line dan offline. Jadi jika waktu ketetapan antara lembaga dan tugas sekolah daring bertabrakan maka siswa/peserta didik akan kualangen dan kesulitan untuk fokus.

f. Takut mencoba aplikasi baru

Tidak semua siswa/peserta didik pandai memainkan IT, terutama pada siswa/peserta didik yang sudah ibu-ibu, mereka akan banyak mengalami kesulitan karena takut mencoba. Ada salah satu Guru/Ustadz/Dosen/Pendidik yang menganjurkan untuk menggunakan aplikasi edmodo, aplikasi zoom, dan google class. Akan tetapi siswa/peserta didik yang sudah menjadi seorang ibu itu tidak mau ambil pusing. Dan alhasil dia lebih memilih pergi ketetangga dekatnya yang masih muda dan pandai IT untuk memberi pengarahan dan pengajaran serta pembimbingan.

g. Guru/Ustadz/Guru/Ustadz/Dosen/Pendidik

Kendala yang dialami oleh Guru/Ustadz/Guru/Ustadz/ Dosen/Pendidik adalah, mereka tidak bisa nyaman dalam penyampaian materi ataupun pemantauan presentasi setiap siswa/peserta didiknya dikarenakan adanya sekolah daring ini. Siswa/peserta didikpun juga sebenarnya kesulitan dan mengalami kesukaran saat mendapat tugas yang hanya dijelaskan tanpa face to face.

Karena kendala yang dialami para Guru/Ustadz/ Dosen/Pendidik tersebut bisa menurunkan semangat belajar siswa/peserta didiknya, maka beberapa dari mereka menggunakan aplikasi atau situs baru. Beberapa diantaranya adalah zoom, edmodo, google class dll. Meski 
sebagian besar masih banyak Guru/Ustadz/Dosen/Pendidik yang melakukan pembelajaran hanya sebatas menggunakan WA.

Profil Responden

\begin{tabular}{|c|c|c|c|c|}
\hline Inisial & $\begin{array}{l}\text { Jenis } \\
\text { kelamin }\end{array}$ & Usia & Kedudukan & Status \\
\hline MR.Y & Perempuan & $\begin{array}{l}30 \\
\text { tahun }\end{array}$ & Siswa/peserta didik & Menikah \\
\hline MR.X & Perempuan & $\begin{array}{l}25 \\
\text { tahun }\end{array}$ & Siswa/peserta didik & $\begin{array}{l}\text { Belum } \\
\text { Menikah }\end{array}$ \\
\hline MR.Z & Perempuan & $\begin{array}{l}20 \\
\text { tahun }\end{array}$ & Siswa/peserta didik & $\begin{array}{l}\text { Belum } \\
\text { Menikah }\end{array}$ \\
\hline MR.P & Perempuan & $\begin{array}{l}40 \\
\text { tahun }\end{array}$ & $\begin{array}{l}\text { Guru/Ustadz/Guru/Ustadz/ } \\
\text { Dosen/Pendidik }\end{array}$ & Menikah \\
\hline MR.O & $\begin{array}{l}\text { Perempuan } \\
\text { dan Laki- } \\
\text { laki }\end{array}$ & $\begin{array}{l}45-50 \\
\text { tahun }\end{array}$ & Orang Tua & Menikah \\
\hline
\end{tabular}

Dari gambar diatas, beberapa responden mengungkapkan sebagai berikut.

Responden MR.Y "saya kesulitan dalam belajar online seperti ini, apalagi saya sudah menikah, walaupun itu tidak bisa dijadikan alasan sih.... tapi saya tetap melakukannya karena ini memang demi kebaikan semuanya"

Responden MR.X "dulu saya kira, belajar online itu mudah dan menyenangkan karena tidak melelahkan dengan perjalanannya, akan tetapi semua terasa berbeda dan benar-benar berbeda. Saya lebih suka sekolah aktif, selain itu HP saya juga belum terlalu canggih dalam hal menangkap sinyal, keadaan rumah saya terbilang dalam pelosok"

Responden MR.Z " saya kesulitan karena kapasitas HP saya tidak sama dengan teman-teman saya, terlebih lagi terlalu sering menyimpan file banyak dan online setiap saat, menjadi tambah lemot. Kapan ya sekolahnya masuk lagi, semoga saja"

Responden Guru/Ustadz/Dosen/Pendidik "saya juga berharap bisa secepatnya bertemu, untuk itu saya berusaha meningkatkan kualitas siswa/peserta didik saya dengan cara saya mengenalkan mereka pada aplikasi Zoom, dan juga laman Edmodo dan google class, agar mereka lebih berkembang lagi tidak hanya menggunakan WA saja. Meski sempat ada bentrok kecil dengan mereka tapi saya iklas tidak apa-apa, karena pada akhirnya mereka juga menurut, alhamdulillah"

Responden MR.O "saya sebagai orang tua memaklumi jika dia capek fikiran dan matanya, saya hanya berharap yang terbaik saja, selebihnya saya hanya mendukungnya saja" 
Formulasi saat ini mengacu pada kecanggihan teknologi yang harus dicoba dan dikembangkan, selain memudahkan dalam sekolah daring, juga sebagai bentuk pengalaman yang berharga yang berkaitan dengan Covid ini. Selain itu, banyak sekali penelitian lain juga mengungkapkan bahwa implementasi pendidikan online meningkatkan kualitas dan evektifitas pendidikan. Dalam dunia pendidikan online sangat memerlukan rangkaian dan rancangan kinerja yang matang yang harus diterapkan antara Guru/Ustadz/Dosen/Pendidik dan siswa/peserta didik. (Zhao, 2003) Rangkaian dan rancangan yang dimaksud adalah sesuatu yang mampu memberikan panduan yang simpel dan praktis kepada para pelaku kepentingan sekolah daring sebagai bentuk kualitas pembelajaran yang harus diacungi jempol.

Dalam pandangan Chakraborty ia menungkapkan bahwa ada beberapa faktor yang bisa memunculkan beberapa pengalaman belajar yang unik dan berbeda dengan yang lainya, yang dihasilkan dari pembelajran online. (Chakraborty, et.al.2014). Faktor utama yang dimaksudkan adalah : menciptakan serta memelihara lingkungan belajar yang bersifat positif, membangun komitmen sebagai komunitas belajar, memakai teknologi yang tepat dan cepat untuk setiap aktivasinya, dan sebagai umpan balik.

Dengan meningkatnya pembelajaran online menjadi peluang bagi siswa/peserta didik saat ini, para petinggi harus mempertimbangkat kenaikan potensi dan rancangan instruksi pembelajaran online yang efektif. ( Lewis, et.al. 2015), Siswa/peserta didik yang melakukan pembelaran secara online harus mengembangkan potensi dan semangatnya sendiri, agar pembelajaran online ini berjalan sukses tanpa kendala meski kendala selalu menghampiri. Semua itu membutuhkan pemahaman yang matang sebelum menempatkan niat yang tetap sebagai bentuk dari gaya belajar dan bagaimana mereka mampu mengendalikan lingkungan online dengan baik dan benar. Saat ini siswa/peserta didik hanya diberi dua pilihan, tetap mengikuti pembelajaran online seiring semakin canggihnya teknologi atau monoton saja dan hanya melakukan pembelajaran online dengan standart kapasitas yang rendah.(Suhendro, 2020)

Watson menjelaskan pembelajaran campuran sebagai kombinasi antara segmen terbaik dari pembelajaran vis-à-vis dan pembelajaran berbasis web. Sesuatu yang sangat mirip juga dikomunikasikan oleh Graham yang mengkarakterisasi pembelajaran campuran sebagai perpaduan yang diperoleh dari dua model pengukuran pembelajaran yang dapat diverifikasi, khususnya antara kerangka pembelajaran konvensional (mata ke mata) dan kerangka pembelajaran yang. Kerangka pembelajaran yang beredar terjadi karena penggunaan kemampuan inovasi elektronik yang luar biasa, terutama PC dan web, sehingga dapat digunakan oleh siapa saja untuk beradaptasi di mana saja dan kapan saja.

Lebih jauh lagi, Bonk dan Graham menyatakan bahwa adaptasi campuran secara fundamental mengkonsolidasikan bagian positif dari dua 
jenis kondisi pembelajaran, khususnya pembelajaran di ruang belajar dan pembelajaran berbasis web Strategi semacam ini sebenarnya sama halnya dengan pembelajaran dikelas sat bertatap muka, pilihanya ada pada siswa/peserta didiknya yaitu memilih melakukan bembejaran lama atau yang baru. Semua itu adalah pilihan terkait dengan pembelajaran online I I hendak nya Guru/Ustadz/Dosen/Pendidik dan siswa/peserta didik harus sama-sama bekerjasama demi menanggulangi resiko yang paling buruk yaitu kejenuhan dan kebosanan.

Sekolah pada masa lanjut adalah pelatihan yang seharusnya mengoordinasikan Teknologi Informasi dan Komunikasi ke mata semua orang olahraga. Dengan peningkatan pendidikan usia lanjut Memberdayakan siswa untuk mendapatkan informasi yang berlimpah juga cepat dan sederhana. Memperhatikan kesulitan pelatihan di jaman komputerisasi ini, pada saat itu instruktur Selain itu, pelajar di abad ke-21 harus memiliki pilihan untuk berkomunikasi dan menyesuaikan diri untuk diikuti Peningkatan kesempatan, karena situasi ini adalah kemajuan inovasi, selain itu dengan kemajuan nonstop periode, itu langsung berhubungan dengan kemajuan masalah yang membutuhkan tujuan dengan pemikiran permintaan yang lebih tinggi. Masalah yang dihadapi adalah globalisasi, perkembangan keuangan, persaingan di seluruh dunia, masalah alam, sosial, dan kebijakan yang didorong, masalah yang membingungkan ini menyebabkan signifikansi luar biasa dalam menciptakan kapasitas dan informasi untuk pencapaian di abad ke-21. Pemahaman perlu berpikir untuk memiliki opsi untuk membalas masalah yang dihadapi wajah dan sekolah harus memiliki pilihan untuk itu mendorong untuk menciptakan kemampuan berpikir.

Selain siswa/peserta didik dan Guru/Ustadz/Dosen/Pendidik sebagai bentuk kerjasama utam, ada faktor lain yang juga menjadi faktor penting yaitu faktor lingkungan yang mendukung. Sperti yang telah disebutkan diatas, lingkungan yang mendukung maksudnya adalah lingkungan yang mampu mendukung keadaan siswa/peserta didik dan konektifitasnya, seperti signyal, pelosok dan pedalaman, juga ekonomi bahkan orang tua. Siswa/peserta didik membutuhkan pembelajaran online dan lingkungan pembelajaran yang sama dan sebangun. Kurangnya penambahan kursus dan praktikum menghasilkan kebosanan dan kurangnya tantangan. (Butler Kaler, 2012) Siswa/peserta didik memiliki tingkat kemampuan dan kecepatan berfikir secara masing-masing dalam takaran yang berbeda-beda sesuai kemampuanya, selama mereka menikmatai kebebasan yang terkendali, tantangan yang berlangsung dan sebuah kemamndirian melakukan pembelajaran online, maka kualitas pun akan meningkat.

Dampak dari covid ini tidak hanya menyerang dunia pendidikan saja, akan tetapi juga duniaperekonomian diseluruh dunia. Miris yang dirasakan dunia saat ini termasuk indonesia benar-benar menyulitkan semua kalangan usia, pada masyarakat biasa tidak pernah ada bayangan ilustrasi seperti ini, 
covid ini. Banyak negara mengambil kebijakan berupa libur dan berdiam diri dirumah, akan tetapi ini sungguh kejadian yang menyulitkan trik belajar dalam pembelajaran. Indonesia mengeluarkan kebijaksanaanya berupa belajar dengan konsep daring. Untuk saat ini, kebijaksanaan ini adalah kebijaksanaan yang paling ampuh dan masih berjalan aktif. Semua usaha yang dilakukan pemerintah adalah untuk kebaikan masyarakatnya. Jadi baik adanya harus mentaati peraturan yang berlaku.

\section{Kesimpulan}

Semenjak adanya Covid-19 ini, aspek ekonomi didunia semakin merosot begitu juga dengan dunia pendidikan, termasuk pada Perguruan Tinggi serta Ponpes. Sistem sekolah daring dilakukan mulai bulan maret 2020. Bukan hanya pada indonesia saja tetapi pada seluruh dunia. Formulasi yang tepat dalam judul ini mengacu pada rumusan dan susunan dalam bentuk yang tepat berupa dampak yang terjadi kepada para siswa/peserta didik dan Guru/Ustadz/Dosen/Pendidik dalam masa pandemi Covid-19 ini di Lembaga Pendidikan di Nganjuk.

Dengan adanya metode belajar jarak jauh, siswa/peserta didik dan Guru/Ustadz/Dosen/Pendidik perlu waktu untuk beradaptasi dengan keadaan belajar baru. Adapun beberapa dampak yang terjadi kepada siswa/peserta didik yaitu kurangnya fasilitas yang memadahi dari siswa/peserta didik, sarana prasarana yang tidak mendukung seperti referensi dan buku-buku. Begitu juga dengan model belajar praktikum. Dampak yang terjadi kepada Guru/Ustadz/Dosen/Pendidik adalah terjadinya kekhawatiran kepada siswa/peserta didiknya dalam mengembangkan potensi-potensi siswa/peserta didik dalam mengembangkan teori tanpa adanya peragaan dari sang Guru/Ustadz/Guru/Ustadz/Dosen/Pendidik.

Sedangkan kendala dan upaya yang dilakukan siswa/peserta didik pun ada. Kendala yang dimaksud adalah kapasitas dan kualitas hp, siswa/peserta didik berkeluarga, susah signyal, ekonomi, Guru/Ustadz/Guru/Ustadz/Dosen/Pendidik, banyak tugas wajib dan takut mencoba aplikasi baru. Sedangkan upaya untuk menanggulangi kendala itu semua adalah tetap semangat dan juga tetap mengikuti peraturan dari kampus dan pemerintah yang sudah disosialisasikan. Terbukti dengan adanya responding dari tematik responder yang sudah tertera diatas.

Adanya tuntutan untuk meningkatkan kualitas sekolah daring dengan cara memberi sifat positif dalam setiap pembelajaranya, menyelaraskan dengan keadaan, dan mengembangkan teknologi yang semakin canggih. Perlunya kerjasama antara Guru/Ustadz/Dosen/Pendidik dan siswa/peserta didik yang mengacu kepada kualitas siswa/peserta didik yang tidak boleh menurun karena adanya sekolah daring ini.

Dampak dari covid ini yang paling utama adalah menyerang dalam dunia ekonomi, dimana ketika ada pembayaran pada kampuspun 
siswa/peserta didik sedikit terbebani, semua itu hanya akan dipasrahkan sesuai keadaan saja. Dalam dunia pendidikan pun covid berhasil merajai. Akan tetapi pemerintah telah mengeluarkan kebijakan yang wajib dipatuhi dan dilaksanakan oleh masyarakat.

\section{REFERENSI}

Ahmat, N., \& Suharto, T. (2017). Konsep Pendidikan Islam Multikultural dalam Pemikiran Ir. Soekarno. In SKRIPSI.

Asror, A. (2014). Rekonstruksi Keberagamaan Santri Jawa. ISLAMICA: Jurnal Studi Keislaman, 7(1), 1. https://doi.org/10.15642/islamica.2012.7.1.1-23

Baihaqi, M. B. (2017). Pendidikan dan Digitalisasi di Era Milenial. Sabtu, 23/12/17.

Diplan, D. (2019). Tantangan Pendidik di Era Digital. Lentera: Jurnal Pendidikan, 14(2), 41-47. https://doi.org/10.33654/jpl.v14i2.888

Fatah, A. (2014). Dimensi Keberhasilan Pendidikan Islam Program Tahfidz Al-Qur'an. Edukasia: Jurnal Penelitian Pendidikan Islam, 9(2). https://doi.org/10.21043/edukasia.v9i2.779

Lubis, M. (2020). Peran Guru Pada Era Pendidikan 4.0. Eduka: Jurnal Pendidikan, Hukum, Dan Bisnis. https://doi.org/10.32493/eduka.v4i2.4264

Machsun, T. (2017). Pembaruan Pendidikan Agama Islam di Madrasah. EL-BANAT: Jurnal Pemikiran Dan Pendidikan Islam.

Ningtias, R. K. (2018). Modernisasi Sistem Pembelajaran Pendidikan Agama Islam Di Lembaga Pendidikan Islam Muhammadiyah Dan Nahdlatul Ulama: Studi di Pondok Pesantren Karangasem Muhammadiyah dan Pondok Pesantren Sunan Drajat Kecamatan Paciran Kabupaten Lamongan. Tadrib: Jurnal Pendidikan Agama Islam. https://doi.org/10.19109/tadrib.v3i2.1794

Nurul Yaqin. (2017). Tantangan Guru di Era Digital. Republika.

Salim, H. (2019). Penelitian Pendidikan : Metode, Pendekatan, dan Jenis. In Jakarta: Kencana.

Suhendro, E. (2020). Strategi Pembelajaran Pendidikan Anak Usia Dini di Masa Pandemi Covid-19. Jurnal Golden Age.

Wahyono, P., Husamah, H., \& Budi, A. S. (2020). Guru profesional di masa pandemi COVID-19: Review implementasi, tantangan, dan solusi pembelajaran daring. Jurnal Pendidikan Profesi Guru. 
Evaluasi: Jurnal manajemen Pendidikan Islam

ISSN (P): 2580-3387, ISSN (E): 2615-2886

Vol. 5 No. 2 September 2021

Zhao, F. (2003), "Enhancing the quality of online higher education through measurement", Quality Assurance in Education, Vol. 11 No. 4, pp. 214-221. 